\title{
KAJIAN PEMILIHAN SUMBER MIKROORGANISME SOLID PHASE MICROBIAL FUEL CELL (SMFC) BERDASARKAN JENIS DAN VOLUME SAMPAH, POWER DENSITY DAN EFISIENSI PENURUNAN COD
}

\author{
Ganjar Samudro, Syafrudin, Winardi Dwi Nugraha, Ika Bagus Priyambada, Hilma \\ Muthi’ah, Glory Natalia Sinaga dan Rahmat Tubagus Hakiem \\ Departemen Teknik Lingkungan, Fakultas Teknik, Universitas Diponegoro, Jl. Prof. H. Soedarto, SH, Tembalang, \\ Semarang \\ Email: ganjarsamudro@gmail.com
}

\begin{abstract}
Abstrak
Mikroorganisme merupakan salah satu komponen penting dalam proses Solid Phase Microbial Fuel Cell (SMFC) untuk degradasi bahan organik dan transfer elektron. Pemilihan sumber mikroorganisme menjadi metode yang paling sederhana untuk dikaji sebagai informasi awal ketersediaan dan identifikasi jenis mikroorganisme yang mendukung proses SMFC. Tujuan kajian ini adalah untuk memilih sumber mikroorganisme tanah, septic tank dan sedimen sungai yang tepat digunakan dalam proses SMFC berdasarkan jenis dan volume sampah, power density, dan efisiensi penurunan COD. Kajian ini didasarkan pada hasil penelitian menggunakan reaktor SMFC tipe single chamber microbial fuel cell dengan variabel jenis dan volume sampah serta sumber mikroorganisme. Metode perbandingan secara kuantitatif dilakukan berdasarkan kecenderungan nilai power density dan efisiensi penurunan COD tertinggi di antara jenis dan volume sampah kantin, dedaunan dan komposit kantin-dedaunan. Hasil yang didapatkan adalah sumber mikroorganisme tanah dan sedimen sungai tepat digunakan untuk volume sampah 1/3 dan 2/3 dari volume reaktor, sedangkan sumber mikroorganisme septic tank tepat digunakan untuk volume sampah 1/3 dan 1/2 dari volume reaktor. Sumber mikroorganisme dari septic tank menunjukkan kinerja power density dan efisiensi penurunan COD yang lebih rendah dibandingkan sumber mikroorganisme tanah dan sedimen sungai.
\end{abstract}

Kata kunci: SMFC, sumber mikroorganisme, jenis dan volume sampah, power density, efisiensi penurunan COD

\section{Abstract}

Microorganism is an important component in the Solid Phase Microbial Fuel Cell (SMFC) process for the degradation of organic matter and the electron transfer. The selection of microorganism sources is the simplest method to be examined in order to know the availability of the microorganisms and to identify the types of microorganisms that support the SMFC process. The aim of this study is to select the sources of microorganism namely soil, septic tank and river sediment which are approriate to be used in the SMFC process based on the type and volume of waste, power density and COD removal efficiency. This research used the single chamber microbial fuel cell type of SMFC reactor. The variables in this study were type of waste, volume of waste, and the microorganism sources. The quantitative comparison method was conducted based on the highest trend of power density and COD removal efficiency between the types and volumes of the canteen, leaves litter and canteen-leaves litter composite waste. The result obtained show that the soil and river sediment microorganism sources were appropriate to be applied for the volume of waste of 1/3 and 2/3 of the reactor volume while the septic tank microorganism source was appropriate for the volume of waste of $1 / 3$ and 1/2 of the reactor volume. The septic tank microorganism source showed a lower performance of power density and COD removal efficiency than the soil and river sediment microorganism sources.

Keywords: SMFC, microorganism source, type and volume wastes, power densty, COD removal efficiency

\section{PENDAhuluan}

Mikroorganisme merupakan komponen penting dalam proses Solid Phase Microbial Fuel Cell (SMFC) untuk degradasi bahan organik dan transfer elektron. Mikroorganisme dapat memanfaatkan limbah bahan organik dengan berbagai kondisi dan sangat adaptif dengan perubahan lingkungan di 
sekitarnya. Sumber mikroorganisme merupakan wadah atau media dimana mikroorganisme hidup dan beradaptasi di dalamnya, serta representatif ketersediaannya di berbagai media di alam, seperti tanah, septic tank, sedimen sungai, kompos, sampah, dan lain sebagainya, yang diidentifikasi sebagai mikroorganisme dominan di dalam reaktor SMFC. Sumber mikroorganisme yang tepat dapat meningkatkan kinerja SMFC. Jenis bakteri yang berperan dalam limbah makanan sebagai salah satu bentuk limbah padat disusun ke dalam tiga kategori, yaitu exoelectrogens, fermentative bacteria, dan specific-functional bacteria (Jia dkk., 2013). Populasi dominan bakteri dimiliki oleh Geobacter (37,72\%) dan Bacteroides (34,66\%) (Jia dkk., 2013). Geobacter sebagai genus dari filum Proteobacteria dan berfungsi ganda sebagai pendegradasi bahan organik dan transfer elektron, serta Bacteroides sebagai filum dari bakteri gram negatif dan berfungsi dominan sebagai pendegradasi bahan organik. Geobacter menggunakan proporsi tertinggi di semua genus dan memainkan kunci untuk membangkitkan daya. Geobacter tidak dapat menggunakan limbah makanan secara langsung meskipun mengandung bermacam-macam bahan organik dan energi yang dapat di-recover berlebih, sama dominannya dari fermentative bacteria yang krusial dalam sistem operasi Microbial Fuel Cell (MFC) (Jia dkk., 2013). Bacteroides dilaporkan dapat menghidrolisis organik kompleks (Rismani-Yazdi dkk., 2013). Menurut Jia dkk. (2013), kombinasi exoelectrogenic Geobacter dan fermentative Bacteroides mendorong efisiensi yang tinggi dan sistem MFC yang dapat diandalkan dengan fungsi dari degradasi bahan organik dan pembangkit listrik. Sumber mikroorganisme tanah secara umum terdapat bakteri filum Bacteroides, sedangkan sumber mikroorganisme septic tank secara umum terdapat bakteri filum Bacteroides dan Proteobacteria, dan sumber mikroorganisme sedimen sungai secara umum juga terdapat bakteri genus filum Bacteroides dan Proteobacteria, yang sama dengan sumber mikroorganisme tanah. Keberadaan bakteri dalam tanah teridentifikasi dalam filum Acidobacteria, Acinobacteria, dan Bacteroides (Fierer dkk., 2007; Liles dkk., 2003; Tringe dkk., 2005). Keberadaan bakteri dalam septic tank teridentifikasi dalam filum Gammaproteobacteria genus Escherichia, Shigella, Salmonella, Legionella, Vibrio (Mara dan Horan, 2003; Lusk dkk., 2011; Bradshaw dan Radcliffe, 2011; Appling dkk., 2013), Campylobactereceae (Mara dan Horan, 2003; Bradshaw and Radcliffe, 2011; Appling dkk., 2013), Shewanella (Sharma dan Kalawat, 2010) dan filum Spirochaetes genus Leptospora (Mara dan Horan, 2003; Lusk dkk., 2011). Sedangkan keberadaan bakteri dalam sedimen sungai teridentifikasi dalam filum Proteobacteria genus Escherichia, Salmonella, Desulfovibrio, Desulfobacteria, Acidovorax (Ren dkk., 2007; Wu dkk., 2013; Sun dkk., 2015; Mitov dkk., 2015) dan Nitobacteria (Jiang dkk., 2015), serta sebagian dalam filum Acidobacteria dan Acinobacteria (Wu dkk., 2013), filum Nitrospirae genus Nitrospira (Wu dkk., 2013), filum 
Bacteroides genus Flavobacterium (Sun dkk., 2015), filum Firmicutes genus Clostridium (Mitov dkk., 2015). Klasifikasi bakteri berdasarkan keberadaannya di dalam suatu media alam, menjadi awal identifikasi bakteri SMFC ataupun varian MFC lainnya secara lebih detail, khususnya dalam penentuan proporsi keberadaan bakteri genus Geobacter dan filum Bacteroides yang berperan dalam MFC dan variannya.

Tujuan kajian ini adalah untuk memilih sumber mikroorganisme tanah, septic tank dan sedimen sungai yang tepat digunakan dalam proses SMFC berdasarkan jenis dan volume sampah, power density, dan efisiensi penurunan COD.

\section{METODE PENELITIAN}

Metode perbandingan secara kuantitatif dilakukan berdasarkan kecenderungan nilai power density dan efisiensi penurunan COD tertinggi di antara jenis dan volume sampah kantin, dedaunan dan komposit kantin-dedaunan. Langkah-langkah metode ini diketengahkan sebagai berikut:

a. Penelitian SMFC dengan variabel jenis sampah kantin, dedaunan dan komposit kantin-dedaunan dan volume sampah $1 / 3 ; 1 / 2$; dan $2 / 3$ dari volume reaktor SMFC, serta sumber mikroorganisme tanah, septic tank dan sedimen sungai, terhadap parameter kinerja power density dan efisiensi penurunan COD terukur selama selang waktu H0; H1; H3; H5; H9; H11; H13; H14; H15; H17; H19; H21; H23; H30 dan H44. Tabel 1 merupakan total power density dan rata-rata penurunan COD dari waktu optimum H11 hingga H44.

b. Perbandingan hasil kinerja power density dan efisiensi penurunan COD dari penggunaan mikroorganisme tanah, septic tank dan sedimen sungai dengan jenis sampah kantin, dedaunan dan komposit kantin-dedaunan dan volume sampah 1/3; 1/2; dan 2/3 dari volume reaktor SMFC. Gambar 1 merupakan grafik perbandingan hasil kinerja.

c. Perbandingan efisiensi penurunan COD berdasarkan hasil penelitian Jia dkk. (2013) dan Nastro dkk. (2017) dimana range efisiensi penurunan COD dalam composite food waste pada SMFC 76 - 86,4\%, serta power density berdasarkan penelitian Song dkk. (2014) dimana power density yang dihasilkan dari penggunaan sampah daun di atas $190 \mathrm{~mW} / \mathrm{m}^{2}$.

\section{HASIL DAN PEMBAHASAN}

Poin 1 pada metode penelitian diketengahkan pada Tabel 1 mengenai hasil analisis Power Density $(P D)$ dan \% Removal COD. Poin 2 pada metode penelitian diketengahkan pada Grafik 2 mengenai perbandingan kinerja sumber mikroorganisme. 
Tabel 1. Hasil Analisis PD dan \%Removal COD

\begin{tabular}{|c|c|c|c|}
\hline \multirow{2}{*}{ Sumber Mikroorganisme } & \multirow{2}{*}{ Jenis-Volume Sampah } & \multicolumn{2}{|c|}{ Parameter Kinerja } \\
\hline & & $\mathrm{PD}^{1}\left(\mathrm{~mW} / \mathrm{m}^{2}\right)$ & $\%$ COD removal² \\
\hline \multirow{9}{*}{ Tanah } & Dedaunan-1/3Vol & 47,90 & 64,62 \\
\hline & Dedaunan-1/2Vol & 23,60 & 76,52 \\
\hline & Dedaunan-2/3Vol & 37,15 & 80,24 \\
\hline & Kantin-1/3Vol & 2,82 & 89,03 \\
\hline & Kantin-1/2Vol & 7,14 & 79,24 \\
\hline & Kantin-2/3Vol & 147,09 & 77,96 \\
\hline & Komposit-1/3Vol & 123,05 & 90,92 \\
\hline & Komposit-1/2Vol & 17,93 & 91,43 \\
\hline & Komposit-2/3Vol & 190,19 & 92,78 \\
\hline \multirow{9}{*}{ Septic Tank } & Dedaunan-1/3Vol & 32,85 & 79,55 \\
\hline & Dedaunan-1/2Vol & 22,61 & 69,59 \\
\hline & Dedaunan-2/3Vol & 6,42 & 71,72 \\
\hline & Kantin-1/3Vol & 28,28 & 81,97 \\
\hline & Kantin-1/2Vol & 28,39 & 63,63 \\
\hline & Kantin-2/3Vol & 12,00 & 63,72 \\
\hline & Komposit-1/3Vol & 75,04 & 66,69 \\
\hline & Komposit-1/2Vol & 35,03 & 75,51 \\
\hline & Komposit-2/3Vol & 13,98 & 75,44 \\
\hline \multirow{9}{*}{ Sedimen Sungai } & Dedaunan-1/3Vol & 22,30 & 66,98 \\
\hline & Dedaunan-1/2Vol & 128,75 & 80,85 \\
\hline & Dedaunan-2/3Vol & 11,11 & 87,67 \\
\hline & Kantin-1/3Vol & 62,94 & 93,80 \\
\hline & Kantin-1/2Vol & 29,53 & 69,58 \\
\hline & Kantin-2/3Vol & 76,33 & 71,10 \\
\hline & Komposit-1/3Vol & 45,55 & 78,39 \\
\hline & Komposit-1/2Vol & 38,49 & 76,47 \\
\hline & Komposit-2/3Vol & 115,60 & 82,17 \\
\hline
\end{tabular}

\section{Catatan:}

${ }^{1} \mathrm{PD}=$ Power Density $(\mathrm{mW} / \mathrm{m} 2)$ yang dihitung total dari waktu optimum $\mathrm{H} 11$ hingga $\mathrm{H} 44$

${ }^{2} \%$ COD removal = efisiensi penurunan COD yang dihitung rata-rata dari waktu optimum $\mathrm{H} 11$ hingga $\mathrm{H} 44$

Berdasarkan Tabel 1, terlihat bahwa sumber mikroorganisme tanah menunjukkan kinerja total power density dan persentase penurunan COD yang lebih besar dibandingkan sumber mikroorganisme sedimen sungai dan septic tank pada jenis sampah dedaunan, kantin dan komposit, serta volume sampah 1/3; 1/2 dan 2/3 dari volume reaktor SMFC. Kinerja SMFC berturut-turut dari terbesar hingga terkecil ditunjukkan oleh sumber mikroorganisme tanah, sedimen sungai, dan septic tank. Berkorelasi dengan keberadaan bakteri dalam tanah, sedimen sungai, dan septic tank, maka bakteri filum Bacteroides yang dominan terdapat pada sumber mikroorganisme tanah dapat mendorong degradasi bahan organik dan pembangkit listrik (Jia dkk., 2013), sedangkan filum Proteobacteria yang juga umum terdapat dalam sumber mikroorganisme sedimen sungai dan septic tank memiliki fungsi ganda, namun menurunkan kemampuannya dalam degradasi bahan organik 
dan pembangkit listrik. Penurunan kemampuan tersebut dapat juga disebabkan kondisi ketersediaan substrat dan nutrisi, serta faktor-faktor berpengaruh lainnya, seperti $\mathrm{pH}$, suhu, DO, bahan organik kimia lainnya dan mikrobiologi yang berkembang di lingkungan sekitarnya yang belum diidentifikasi secara detail.

Apabila mengacu pada perbandingan antara sumber mikroorganisme sedimen sungai dengan septic tank pada kondisi jenis sampah dedaunan, kantin, dan komposit, serta volume sampah 1/3; 1/2 dan 2/3, maka sumber mikroorganisme sedimen sungai yang mengandung filum Bacteroides dan Proteobacteria menghasilkan kinerja power density dan efisiensi penurunan COD yang lebih merata besarnya dibandingkan sumber mikroorganisme septic tank, dimana sumber mikroorganisme septic tank lebih besar dalam menghasilkan listrik dibandingkan pendegradasi bahan organik. Secara praktis, sumber mikroorganisme sedimen sungai dipilih karena power density dan efisiensi penurunan COD yang lebih besar dan merata dibandingkan sumber mikroorganisme septic tank.

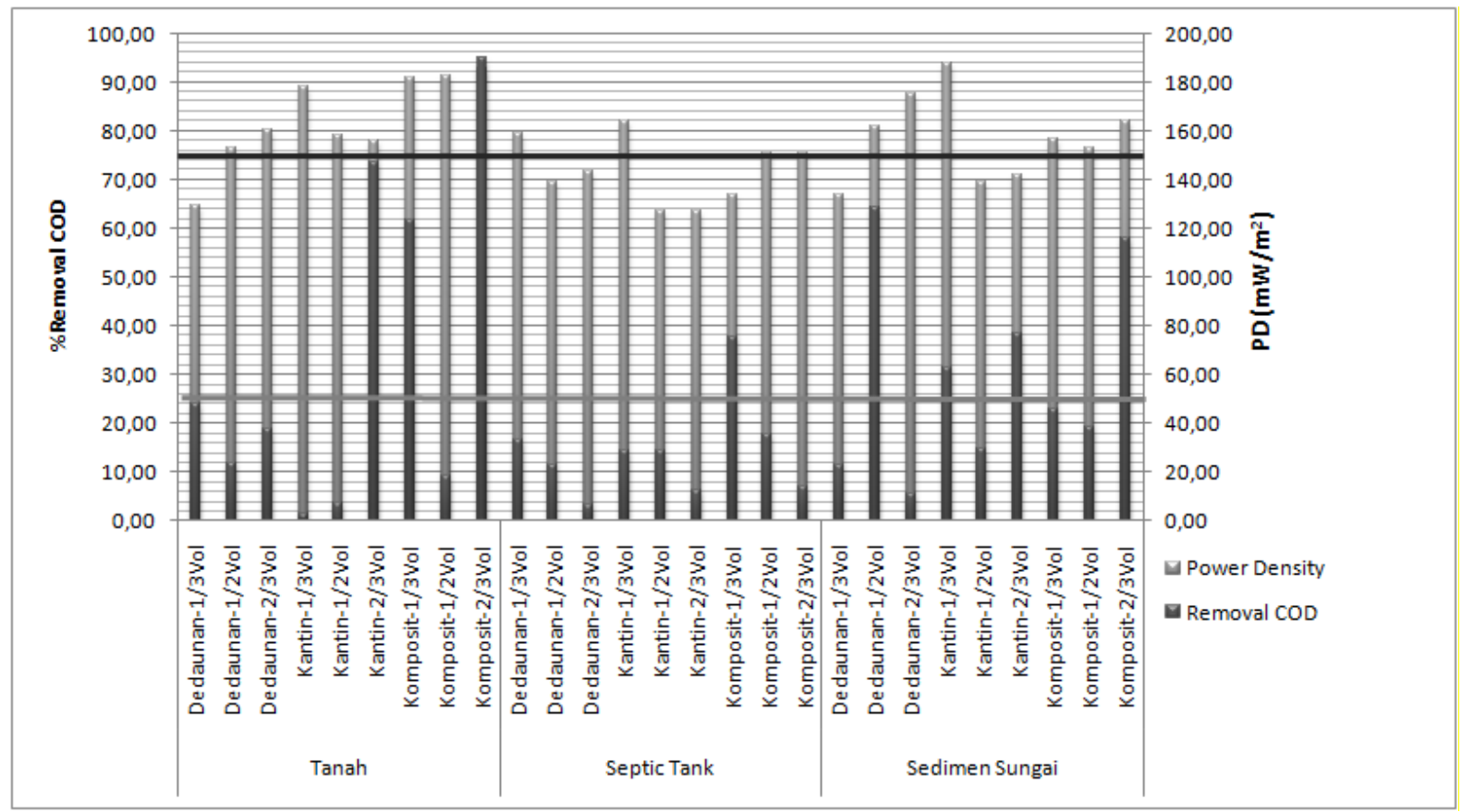

Gambar 1. Perbandingan Kinerja Sumber Mikroorganisme

Berdasarkan Gambar 1 dan hasil penelitian Jia dkk. (2013) dan Nastro dkk. (2017), serta power density berdasarkan penelitian Song dkk. (2014), maka sumber mikroorganisme dengan kinerja power density dan efisiensi penurunan COD di atas minimal $50 \mathrm{~mW} / \mathrm{m}^{2}$ hingga $190 \mathrm{~mW} / \mathrm{m}^{2}$ dan di atas $76 \%$ berturut-turut adalah mikroorganisme tanah, sedimen sungai, dan septic tank. 
Sumber mikroorganisme tanah dengan keberadaan bakteri dominan berupa filum Bacteroides menunjukkan kinerja power density dan efisiensi penurunan COD yang lebih besar dibandingkan sumber mikroorganisme sedimen sungai dan septic tank dengan keberadaan bakteri dominan berupa filum Bacteroides dan Proteobacteria. Sumber mikroorganisme dari septic tank menunjukkan kinerja power density dan efisiensi penurunan COD yang lebih rendah dibandingkan sumber mikroorganisme tanah dan sedimen sungai.

\section{KESIMPULAN}

Sumber mikroorganisme tanah dan sedimen sungai tepat digunakan untuk volume sampah $1 / 3$ dan 2/3 dari volume reaktor, sedangkan sumber mikroorganisme septic tank tepat digunakan untuk volume sampah $1 / 3$ dan $1 / 2$ dari volume reaktor. Sumber mikroorganisme dari septic tank menunjukkan kinerja power density dan efisiensi penurunan COD yang lebih rendah dibandingkan sumber mikroorganisme tanah dan sedimen sungai.

\section{UCAPAN TERIMA KASIH}

Ucapan terima kasih disampaikan kepada Saudari Hilma Muthi'ah, Glory Natalia Sinaga dan Saudara Rahmat Tubagus Hakiem sebagai mahasiswa Tugas Akhir yang membantu dalam penelitian dan Departemen Teknik Lingkungan FT UNDIP, serta Laboratorium Teknik Lingkungan FT UNDIP.

\section{DAFTAR PUSTAKA}

Appling, D., Habteselassie, M.Y., Radcliffe, D., Bradshaw J.K., (2013), Preliminary Study on the Effect of Wastewater Storage in Septic Tank on E. coli Concentration in Summer, Water 2013, 5, 1141-1151; doi:10.3390/w5031141.

Bradshaw, J.K. and Radcliffe, D.E., (2011), Nitrogen Dynamics in a Piedmont Wastewater Treatment System, In Proceedings of the 2011 Georgia Water Resources Conference, Athens, GA, USA, 11-13 April, 2011; Carroll, D., Ed.; Georgia Water Resources Association: Athens, GA, USA, 2011; pp 110-113.

Fierer, N., Bradford, M.A. and Jackson, R.B., (2007), Toward an ecological classification of soil bacteria, Ecology, 88(6), pp.1354-1364.

Jia J, Yu Tang, Bingfeng Liu, Di Wu, Nanqi Ren, Defeng Xing, (2013), Electricity generation from food wastes and microbial community structure in microbial fuel cells, Bioresource Technology, 144: 94-99. 
Jiang, H.L.,Zhou, Y.L., Wu, H.F., Yan, Z.S., Cai, H.Y., (2015), The enhanced survival of submerged macrophyte Potamogeton malaianus by sediment microbial fuel cells. Ecological Engineering, 87, pp.254-262.

Liles, M.R., Manske, B.F., Bintrim, S.B., Handelsman, J. and Goodman, R.M., (2003), A census of rRNA genes and linked genomic sequences within a soil metagenomic library, Applied and Environmental Microbiology, 69(5), pp.2684-2691.

Lusk, M., Toor, G.S. and Obreza, T., (2011), Onsite Sewage Treatment and Disposal Systems: Bacteria and Protozoa.

Mara, D. and Horan, N.J. eds., (2003), Handbook of water and wastewater microbiology, Academic press.

Mitov, M., Bardarov, I., Mandjukov, P., Hubenova, Y., (2015), Chemometrical assessment of the electrical parameters obtained by long-term operating freshwater sediment microbial fuel cells, Bioelectrochemistry.

Nastro, R.A., Falcucci, G., Minutillo, M. and Jannelli, E., (2017), Microbial Fuel Cells in Solid Waste Valorization: Trends and Applications, In Modelling Trends in Solid and Hazardous Waste Management (pp. 159-171), Springer Singapore.

Ren, Z., Ward, T.E. and Regan, J.M., (2007), Electricity production from cellulose in a microbial fuel cell using a defined binary culture, Environmental science \& technology, 41, pp.47814786.

Rismani-Yazdi, H., Carver, S.M., Christy, A.D., Yu, Z., Bibby, K., Peccia, J., Tuovinen, O.H., (2013), Suppression of methanogenesis in cellulose-fed microbial fuel cells in relation to performance, metabolite formation, and microbial population, Bioresour. Technol. 129, 281-288.

Sharma, K.K. dan Kalawat, U., 2010, Emerging infections: Shewanella-a series of five cases, Journal of laboratory physicians, 2(2), p.61.

Song, T.S., Wang, D.B., Han, S., Wu, X.Y. and Zhou, C.C., (2014), Influence of biomass addition on electricity harvesting from solid phase microbial fuel cells, International Journal of Hydrogen Energy, 39(2), pp.1056-1062. 
Sun G., Thygesen A., Meyer A. S., (2015), Acetate is a superior substrate for microbial fuel cell initiation preceding bioethanol effluent utilization, Appl. Microbiol, Biotechnol. 99 49054915. 10.1007/s00253-015-6513-5.

Tringe, S.G., Von Mering, C., Kobayashi, A., Salamov, A.A., Chen, K., Chang, H.W., Podar, M., Short, J.M., Mathur, E.J., Detter, J.C. and Bork, P., (2005), Comparative metagenomics of microbial communities. Science, 308(5721), pp.554-557.

Wu Y., Guan K., Wang Z., Xu B., Zhao F., (2013), Isolation, identification and characterization of an electrogenic microalgae strain, PloS one 8:e73442. 